\title{
An Empirical Study of the Work Conditions and Productive Performance After Collaborative Robotics Implementation in a Manufacturing Assembly Process
}

\author{
Integrated Master in Engineering of \\ Industrial Management \\ University of Minho \\ Portugal \\ José Dinis-Carvalho \\ Associate Professor \\ University of Minho \\ Portugal \\ Nuno Sousa \\ Researcher \\ Algoritmi Research Centre \\ University of Minho \\ Portugal
}

\begin{abstract}
Industry 4.0 has led to a widespread and impactful evolution of technology that is transforming industry and organizations in general. Collaborative robotics is considered one of the new features in this movement allowing humans and robots to work together in perfect collaboration. This paper presents the implementation of one collaborative robot in an assembly process and analyses its impact on performance and ergonomic work conditions. In terms of ergonomic conditions, the musculoskeletal risk was assessed, comparing both processes (without and with robotics support). The results demonstrated that collaborative robotics is a solution that allows improving the ergonomic work conditions throughout the assembly process.
\end{abstract}

Keywords: Industry 4.0; Lean Production; Ergonomics; Collaborative Robotics; Waste reduction.

\section{INTRODUCTION}

The $4^{\text {th }}$ Industrial Revolution - also named Industry 4.0 - is characterized by the fusion of physical, virtual, and technological domains, with emphasis on engi-neering applications such as digitization, automa-tion, and robotics. Industry 4.0 is supposed to lead to sig-nificate change in the production process due to digi-talization, extensive and intelligent process integration and selforganization [1]. Inside the factories, this revolution intends the digital transformation of tradi-tional manufacturing, implementing Smart Working. Smart Working includes technologies to support wor-kers' tasks to enable them to be flexible and more productive. Virtual reality for workers training, aug-mentted reality for product development and colla-borative robots are examples of technologies for Smart Working [2]. This ongoing application of Smart Working has highlighted the role of human workers in these novel processes [3].

Regarding collaborative robotics, and in opposition to traditional robotics, this is characterized by workspace sharing, with no safeguards or fences between robots and humans. Besides, the capability of adaptation to frequent task changes, the safe interaction with humans, and the flexible relocation constitute other potentialities related to collaborative robotics [4-6]. This technology has also been pointed to as a promising solution to reduce the physical workload and to decrease the musculoskeletal risk associated with manufacturing

Received: December 2020, Accepted: September 2021 Correspondence to: Dinis Carvalho, Associate Professor, Universidade do Minho, Departamento de Produção e Sistemas, Guimarães, Portugal.

E-mail: dinis@dps.uminho.pt

doi:10.5937/fme2104859C

(C) Faculty of Mechanical Engineering, Belgrade. All rights reserved tasks, in parallel to the improvement of workplace safety, productivity, and quality $[7,8]$.

In industrial settings, collaborative robotics has assumed several applications with diverse levels of physical Human-Robot Collaborations (HRC). Considering the different definitions and categorization levels existing in the literature, in the current study (as previously described in [9]), we adopted the definition defended by Cesta et al. [10]. The mentioned authors proposed four levels of HRC, namely: (i) independent scenario when the robot and human work separately in workpieces/workprocesses; (ii) simultaneous case in which robot and human work on the same workpiece but in different processes; (iii) sequential scenario, the human-worker and robot work on the same workpiece in a distinct time but dependent processes; (iv) sup-portive is the scenario where robot and human work simultaneously in the same workpiece and process (Figure 1).

(i) Independent (ii) Simultaneous (iii) Sequential (iv) Supportive
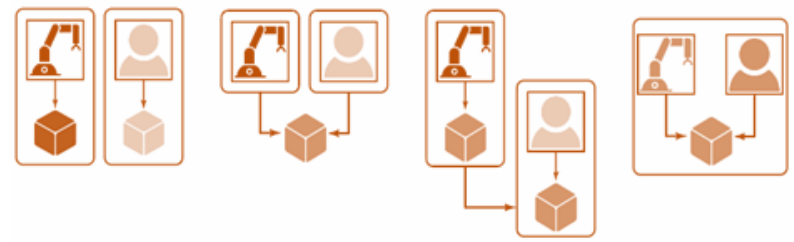

Figure 1 Different levels of HRC (adapted for [6]).

Concerning the current study, robotics implementation in a manual assembly process is one of the intended goals. Robots are pointed to as one of the most notable benefits of Industry 4.0 [11]. Previous studies $[12,13]$ mentioned a future scenario for the manufacturing industry where repetitive, simple, and monotonous tasks will be eliminated or supported by 
introducing robotic solutions. The hybrid teams composed of humans and robots will support the demographic diversity of workers teams, as well as the physical limitations of human workers, where robots help or take over the most demanding physical tasks.

Manual assembly work presents high flexibility, but low productivity compared to a fully automated assembly system. To improve productivity while maintaining flexibility, future assembly systems must incorporate higher levels of robotic solutions, which support or augment human capabilities. In these novel workstations, human workers provide manual work and the design of the system should be oriented by an adaptive utilization of human capabilities, foreseeing the improvement of productivity and workers' wellbeing [14]. Therefore, for the robotics industrial applications, Romero et al [15] highlight that human-centred manufacturing with adaptive automation can potentiate the companies' competitiveness, considering the new social challenges for the factories of the future. These authors defend that the automation/robotic systems have to include various criteria, such as age-, disability- and inexperience-related restrictions of the workers in order to increase their working capabilities, according to a perspective of "Human-automation symbiosis". In contrast to traditional robotic, adaptive work systems allow a dynamic and seamless transition of tasks' allocation between human workers and robots /automation, providing inclusiveness and job satisfaction, simultaneously with the production goals achievement. For the design of these human-centred workstations, the human skills and limitations support the tasks' allocation and the level of automation for system design.

In the manufacturing contexts, optimizing task allocation would increase the systems' robustness due to complementarities of technology efficiency with the flexibility of humans [16]. The Ergonomics scientific area must support these tasks' allocation and the design and implementation of these new work systems [17]. Therefore, the current study aims to analyse the impact of a collaborative robotics workstation throughout an assembly process, considering human factors and production performance. The effect of industry 4.0 technologies in lean environments aiming production performance improvements is already presented in some publication [18]. Moreover, this implementation takes place in a context where Operational Excellence is pursued through concepts and principles aligned with Lean Production [19], Lean Thinking [20], Toyota Way [21], or Shingo Model [22]. In this type of environments humans play the key role in the design of the system and in its overall performance [23]

Since this paper is also about human factors, special attention is paid to the concept of "Muri". The Japanese word "Muri" means physical strain or overburdening. Any actions such as "bending to work", "pushing hard", "lifting heavyweights", "repeating tiring actions", and "wasteful walk" are considered "Muri" and consequently, they must be eliminated according to principles followed by models such as Lean thinking and Toyota Way. These concerns were already present in the initial Toyota Production Systems as it proves the first scientific paper published in English in 1977 [24]. Just to clarify the importance given to human factors, Toyota established the Respect for People as one of their two main pillars, being Continuous Improvement the other one [25].

Having this in mind the objective of this new production configuration with the collaborative robot should improve production performance and production flow by reducing "Muda" [26], [27], as well as improving respect for people by eliminating as much as possible sources of "Muri". However, in the Industry 4.0 research field, the ergonomics and human factors are underrepresented, constituting a relevant research gap [28]. Moreover, Franck et al. [2] argued that exists a lack of studies providing empirical results about the im-pact of Industry 4.0 technologies' implementation in the manufacturing companies. Therefore, the current study aims to contribute to this research gap, analysing the effects of HRC implementation into a real-industry scenario, in terms of ergonomic conditions and productivity.

\section{METHODOLOGY}

The current study is integrated into a research project involving the Collaborative Laboratory DTx, the University of Minho, and a furniture manufacturing company. This project involved a multidisciplinary team, composed of researchers of robotics, ergonomics, and industrial management, as well as the company's managers and workers. In fact, this process intervention was developed with the workers involved, adopting a participatory approach to achieve a higher level of acceptance for the changes proposed [29], [30]. The workers participated in the study voluntarily, and they signed an Informed Consent Term in agreement with the Committee of Ethics for Research in Social and Humans Sciences of the University of Minho (approval number CEICSH 095/2019).

The assembly processes were assessed taking into account one frame reference of the company, because it is the only one that currently has the possibility of being assisted by preassembly. For both assembly processes initial condition and new with cobot in preassembly - a set of Performance Indicators (PI) were measured, in order to assess the impact of the new process in terms of productivity. For this purpose, the company provided the number of pieces that each worker was required to produce during one hour, i.e., Number of frames demanded Per Hour (NPH). In addition, the number of pallets that the workers were capable to produce per hour was also determined. For each process studied, a time study was carried out with a confidence level of, at least, $90 \%$ and a superior error limit error of $\pm 5 \%$. There were observed a total of 10 workers along 25 work cycles. Through direct observation, value analysis of the tasks was made, as well as identified the production wastes. One of the operations adding value to these processes is the glue application. Concerning this task, the glue consumption varies between the processes studied, so it was another PI measured. The glue consumption was measured by weighing cubes with and without glue, extrapolating the consumption of each assembly process (when producing an entire pallet of preforms in preassembly and frames in assembly). 
This was calculated for a preforms pallet of $720 \mathrm{SS}, 360$ of DS, and a pallet of 38 frames.

In order to assess the musculoskeletal risk associated with the work processes, a postural analysis was carried out through the Rapid Upper Limb Assessment (RULA method) [31] considering 57 postures in the preassembly and 73 in each assembly process (initial and final).

RULA is a well-known observational method for assessing Work-related Musculoskeletal Disorders (WMSD) risk for the upper limbs, considering also the neck, trunk, and lower extremities position during work activity. This method is widely applied for musculoskeletal risk assessment related to repetitive and manual tasks [32], as the assembly tasks studied. Its application involves the postures assessment adopted by the worker, as well as the forces exerted, the repetitiveness of movements, and external loads (such as handling heavy materials) [31]. In this study, during the video-records observations, the most frequent and critical postures were selected. For each corporal segment considered, joint angles were determined from digital images imported to LiteCAD ${ }^{\circledR}$, version 2.0.0.48. For each posture, different joint angles were associated with a joint score according to a predefined range of angles. Finally, the weighted RULA score was calculated using (1) where $i$ refers to a task in the process, $\mathrm{R}_{i}$ the RULA assessment for each task, and $t_{i}$ the normalized time per task.

$$
\text { Weighted RULA score }=\frac{\sum R i^{*} t i}{\sum t i}
$$

This procedure leads to a final RULA score, that is related to an action level indicating the urgency of ergonomic intervention, being higher scores related to higher musculoskeletal risk as exposed in Table 1.

\section{Table 1. Meaning of the final RULA scores}

\begin{tabular}{ccl}
\hline $\begin{array}{c}\text { Action } \\
\text { Level }\end{array}$ & $\begin{array}{c}\text { RULA } \\
\text { score }\end{array}$ & \multicolumn{1}{c}{ Meaning } \\
\hline 1 & 1 or 2 & $\begin{array}{l}\text { The posture is acceptable if it is not } \\
\text { maintained or repeated for long periods. }\end{array}$ \\
2 & 3 or 4 & $\begin{array}{l}\text { Further investigation is needed and } \\
\text { changes may be required. } \\
\text { Investigation and changes are required } \\
\text { soon. } \\
\text { Investigation and changes are required } \\
\text { immediately. }\end{array}$ \\
\hline
\end{tabular}

\section{DESCRIPTION STUDY}

\subsection{Initial condition}

The assembly process is carried out on vertical assem-bly workbenches (marked as 2 in Figure 2) where two workers operate simultaneously side by side. The workstation is supplied laterally through stripes carts (marked as 1 in Figure 2), and baskets of blocks arranged under their work plan (marked as 3 in Figure 2) while the final pallets of product are delivered in the back plan of workers production (marked as 4 in Figure 2).

In the assembly initial condition, the workers' function was tocontinuouslyconstruct a frame gluing four types of Medium-Density Fiberboard (MDF) raw stripes and blocks as shown in Figure 3. Being a completely manual process, each work cycle is con-stituted by the following tasks: reach the stripes of the supply cart, arrange them on the workbench, select the blocks of the baskets, apply them hot glue with a glue gun activated by finger pressure, and fix them in proper points to give to the frame the required stability accor-ding to the technical specifications. Once complete, the frame is moved to a pallet and sent to consecutive workstations.

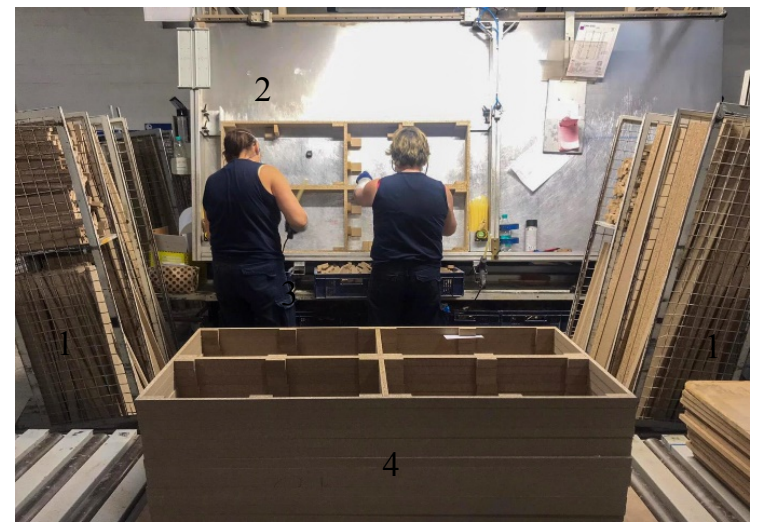

Figure 2 Assembly workstation

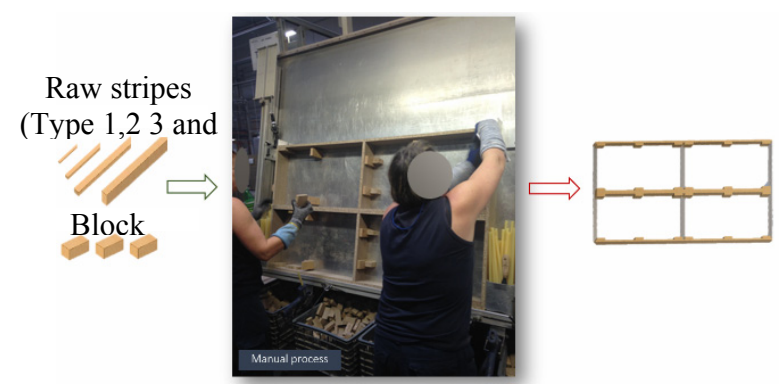

Figure 3 Initial assembly workflow (inputs, example of posture adopted, output).

The NPH for each worker is 40 frames, which means that the takt time required is 90 seconds per frame.

In this configuration, the horizontal stripes handled weight range varies from 1.16 to $2.24 \mathrm{~kg}$. These assembly workers are exposed to several musculoskeletal risk factors, such as repeatability of tasks, manual handling above shoulders, as well as manual overload due to glue applications.

The reports of the company's occupational medicine indicated that some workers developed musculoskeletal disorders related to this type of work, such as carpal tunnel syndrome and herniated discs. Therefore, the company intended to reformulate the assembly process to improve ergonomics conditions.

\subsection{Final condition}

The assembly process was split by the manufacturer managers into preassembly (PA) and final assembly, creating a new manual workstation for the preassembly. The PA was designed to accommodate the assembly workers with previous musculoskeletal disorders (this design phase is described in [17]) with the aim of producing two references of preforms (named simple stripes, SS, and double stripes, DS) that will take part the frames final assembly. 
The new PA workstation was designed to allocate two workers, that operates with collaborative robotics support in which the robotic system supplies the blocks with hot glue to the workers, eliminating the tasks of selecting and picking cubes, as well as applying glue. The main aspect that differentiates collaborative from traditional robotics is the fact that the cobots act without the need for physical separation between the robot and the humans (such as into cages). In this case, the robot acts in an area of free access and which human operators access to supply the entire system (with glue and MDF blocks), without any risk. As this robot is collaborative, with sensorization that allows the detection of "strange" contacts (like a human colliding with the robotic arm) and it stops automatically. This solution is the first level of Human-Robot Collaboration, described earlier, as independent scenario since the robot and human work separately in workpieces /workprocesses. Furthermore, as a certified collaborative robot, it has no sharp edges, is properly programmed and works at speeds that prevent human injuries from possible accidental collision situations.

Once completed, the preforms are sent to be used in the final assembly along with the rest of the raw stripes
(Figure 4). As observed in Figure 5, the new workstation is composed by automation and a collaborative Universal Robot UR10e with a vacuum end-effector. The robotic system dispense MDF blocks with hot-glue to the human workers, who complete the PA process, gluing these blocks to the stripes and palletizing the final product. In this case, the HRC is defined as being a sequential scenario (according to [7]), since robot and workers, are sequentially depen-dent, i.e. one work phase (of robot/workers) can only start when the previous has finished. The NPH for each worker in this process is 70 , which means that the takt time required is 51.4 seconds per frame. In this configuration, the horizontal stripes handled weight range in the final assembly varies from 1.62 to $3.34 \mathrm{~kg}$.

\section{RESULTS AND DISCUSSION}

Table 2 summarizes the main results of the comparison between the initial and the new assembly processes, including the preassembly with collaborative robot support. In all process indicators where it was not reasonable to calculate their sum, these are defined as not applicable (n.a.).

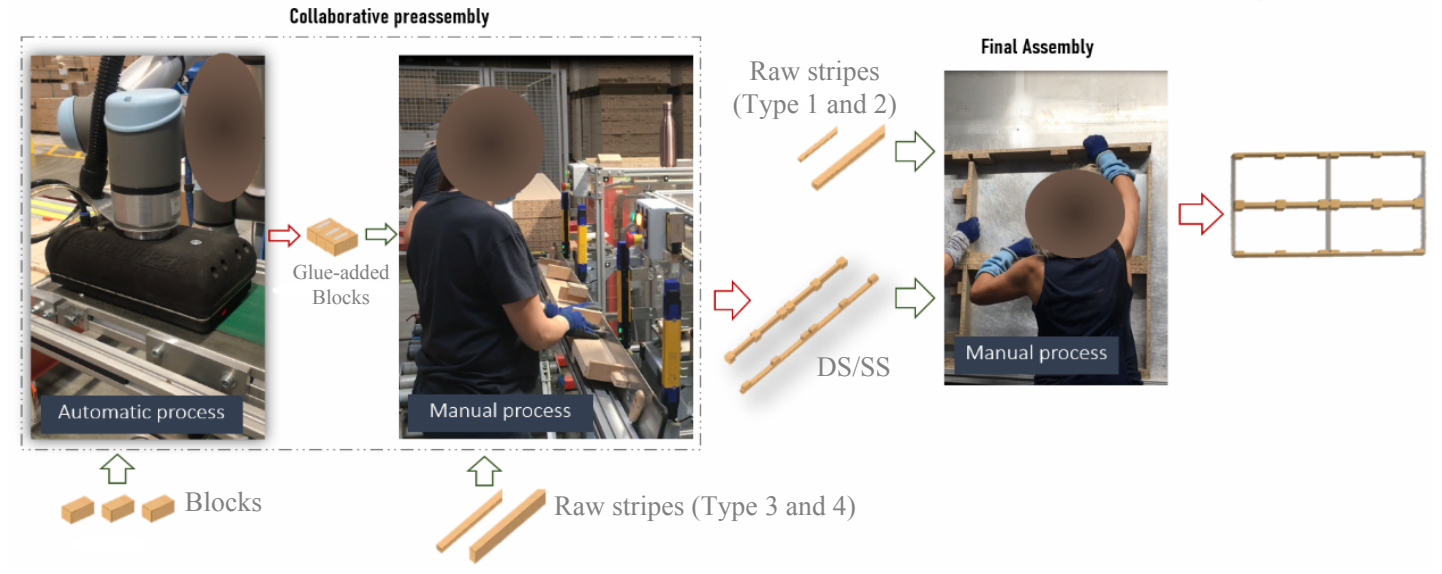

Figure 4 New assembly workflow (inputs, examples of postures adopted, outputs).

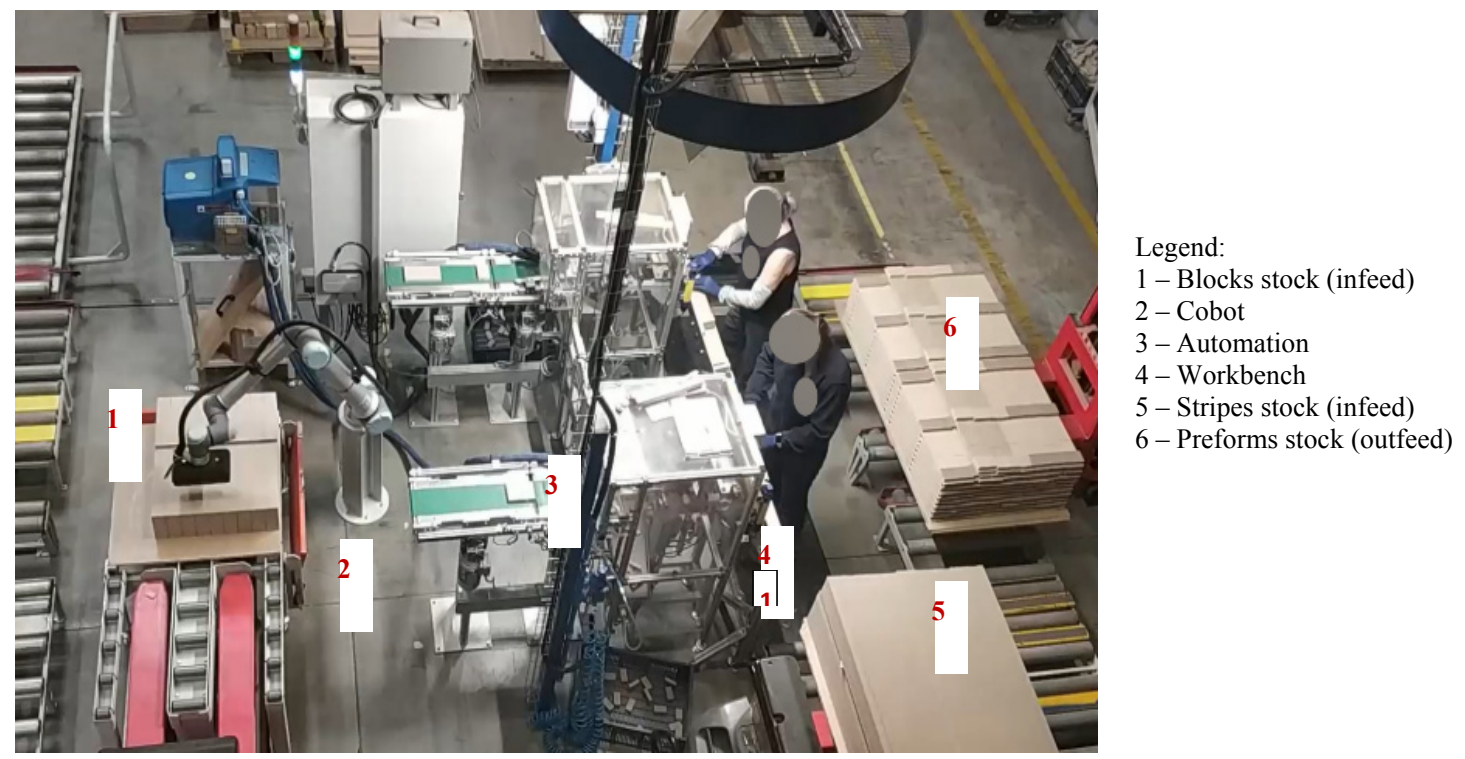

Figure 5 Top view of the new PA workstation. 


\begin{tabular}{|c|c|c|c|c|c|}
\hline & \multirow[b]{2}{*}{ PI } & \multirow[b]{2}{*}{$\begin{array}{c}\text { Initial Assembly } \\
\text { Process }\end{array}$} & \multicolumn{3}{|c|}{ New Assembly Process } \\
\hline & & & Preassembly with cobot & $\begin{array}{c}\text { Final } \\
\text { assembly }\end{array}$ & Global \\
\hline & Standard Processing Time (sec/frame) & $77.90 \pm 5.7$ & $68.20 \pm 6.3$ & $39.80 \pm 3.5$ & $107.10 \pm 9.8$ \\
\hline & NPH & 40 & 140 (DS) / 280 (SS) & 70 & n.a. \\
\hline & Pallets produced per hour & 1.22 & $0.70(\mathrm{DS}) / 0.63(\mathrm{SS})$ & 2.43 & n.a. \\
\hline & Glue consumption $\left(\mathrm{cm}^{3} /\right.$ pallet $)$ & 168.72 & 119.5 & 70.3 & 189.8 \\
\hline & Tasks value $(\%)$ & $43-1-56$ & $42-12-46$ (DS) / 49-5-46 (SS) & $64.5-2-33.5$ & n.a. \\
\hline \multirow{4}{*}{ 疋 } & Number of manual glue applications & 72 & 0 & 30 & 30 \\
\hline & Manual handling above shoulders & 21 & 0 & 10 & 10 \\
\hline & Weight range of manipulated parts $(\mathrm{kg})$ & $1.16-2.40$ & $1.16-2.40$ & $1.62-3.34$ & n.a. \\
\hline & Weighted RULA & 4.90 & 2.90 & 4.90 & 4.37 \\
\hline
\end{tabular}

Legend: PI - Performance Indicators; NPH - Number of pieces (frames) demanded Per Hour; DS - Preform Double stripe; SS Preform Single stripe; n.a. - not applicable.

The new assembly process configuration includes more process steps than initially in order to include the robot. However, in the new assembly process was achieved an increase of productivity and a reduction of musculoskeletal risk for workers, but also resulted in some negative aspects such as an increase in the occupied area and an increase in some forms of production waste. The new assembly process had the result of an increase in the total processing time required to produce one frame as shown in the first row of Table 2. The tasks there were replaced/readjusted in the final assembly were not exclusively the most time consuming ones but the ones with higher muscu-loskeletal risk. As the amount of work allocated to workers was reduced, the normalized cycle time of the assembly process has decreased. Though, when including the time spent on preassembly, that includes stripes handling and extra movements, made the was increased from around 40 frames/worker.hour to 70 frames/worker.hour.

Another effect of this new configuration is glue consumption. The need for having both the robot and the worker putting glue in two different moments resulted in higher glue consumptions in this new assembly process configuration.

Regarding the different types of production waste as defined in the Toyota Production System as well as in Lean Manufacturing literature, there was an increase in waste moments as can be seen in Table 3. This new configuration has more transport moments, more inventory, and more motion. As a divided production, with the new assembly configuration, there is an intermediate process between the storage and the supply carts, which increases the number of carrying tasks and quantity of intermediate stocks.

When analysing the value-adding and non-valueadding tasks in the initial condition, it was found that the proportion on time was higher to non-value-adding tasks (56\% spent on stripes' handling, blocks selection, and palletizing), followed by add-value tasks ( $43 \%$ on applying glue and fixing the blocks) and non-value added tasks but necessary ( $1 \%$ writing a note for quality reasons). According to the time study, the three more time-consuming tasks are the added-value mentioned above, as well as the task of block' selection.
Table 3. Assembly material sequential graphic comparison

\begin{tabular}{|c|c|c|c|c|c|c|c|}
\hline \multicolumn{4}{|c|}{$\begin{array}{c}\text { Traditional Assembly } \\
\text { Process }\end{array}$} & \multicolumn{4}{|c|}{ New Assembly Process } \\
\hline Activity & & & $D$ & Activity & & & \\
\hline $\begin{array}{l}\text { Supply } \\
\text { station } \\
\text { Buffer }\end{array}$ & & & $\bullet$ & $\begin{array}{c}\text { PA } \\
\text { station } \\
\text { buffer }\end{array}$ & & & $\bullet$ \\
\hline $\begin{array}{l}\text { Supply } \\
\text { the cars }\end{array}$ & $\bullet$ & & & $\begin{array}{c}\mathrm{PA} \\
\text { process }\end{array}$ & $\bullet$ & & \\
\hline $\begin{array}{c}\text { Transport } \\
\text { to } \\
\text { assembly } \\
\text { station } \\
\end{array}$ & & $\bullet$ & & Palletize & & & $\bullet$ \\
\hline $\begin{array}{l}\text { Stock at } \\
\text { assembly } \\
\text { station }\end{array}$ & & & $\bullet$ & $\begin{array}{c}\text { Transport } \\
\text { to PA } \\
\text { storage }\end{array}$ & & $\bullet$ & \\
\hline $\begin{array}{c}\text { Frames } \\
\text { assembly }\end{array}$ & $\bullet$ & & & $\begin{array}{c}\text { Transport } \\
\text { to supply } \\
\text { buffer }\end{array}$ & & $\bullet$ & \\
\hline \multirow[t]{6}{*}{ Palletize } & & & $\bullet$ & $\begin{array}{l}\text { Supply } \\
\text { station } \\
\text { Buffer }\end{array}$ & & & $\bullet$ \\
\hline & & & & $\begin{array}{l}\text { Supply } \\
\text { the cars }\end{array}$ & $\bullet$ & & \\
\hline & & & & $\begin{array}{c}\text { Transport } \\
\text { to } \\
\text { assembly } \\
\text { station }\end{array}$ & & $\bullet$ & \\
\hline & & & & $\begin{array}{l}\text { Stock at } \\
\text { assembly } \\
\text { station }\end{array}$ & & & $\bullet$ \\
\hline & & & & $\begin{array}{l}\text { Frames } \\
\text { assembly }\end{array}$ & $\bullet$ & & \\
\hline & & & & Palletize & & & $\bullet$ \\
\hline Total & 2 & 1 & 3 & & 3 & 3 & 5 \\
\hline
\end{tabular}

storage $(\boldsymbol{D})$; Final storage $(\boldsymbol{\nabla})$

In the case of the final assembly, $64.5 \%$ of the processing time is related to tasks that add direct value to the process including the movements involved in fixing the stripes and applying glue. Writing a note 
takes $2 \%$ of the cycle time while palletizing and reaching the stripes (raw or preforms) are non-valueadded tasks that take the rest of the processing time $(33.5 \%)$.

The company selects the workers allocated to PA workstation, being workers physically limited due to musculoskeletal disorders. Therefore, the main benefits of this collaborative cell are related to a positive impact on the ergonomics conditions, productivity, and more efficient use of human resources (mainly those with musculoskeletal disabilities). These results are in line with previous studies that indicated collaborative robotics as a technological solution to improve workstations safety and ergonomics [7], [8].

As the vertical workbenches are also utilized for the new assembly, the musculoskeletal risk factors pointed to the initial assembly cell are still present in this new process configuration. Relatively to the RULA assessment in the vertical workbenches, the main risk factors are the following: (i) repetitiveness of the actions with the glue gun (1500 times per day); (ii) manual handling above shoulders; (iii) awkward postures of the upper body segments (neck flexion, arm abduction, trunk torsion, etc.); and (iv) improper layout of the workstation (inadequate position of inputs, table height). The collaborative robotic cell helps the assembly process by reducing the exposure to risk factors, namely in the reduction of the repetitiveness of gluing tasks and elimination of the manual handling above shoulders and block selection.

Although three frames are built per cycle in both assembly processes, the number of glue points is not the same. A glue point is defined as each unit application of glue in a block and/or stripe with the aid of a glue gun. As in the collaborative PA it is done automatically, between the initial and final assembly there is a $58 \%$ reduction of actions with glue gun per cycle (from 72 to 30 points). The physical effort associated with repetitive glue applications is significantly lower (compared with initial conditions) because the workers used preforms with the blocks glued. In this domain, a previous ergonomic study [17] demonstrated that this is the most critical task for the wrist-hand system.

A manipulation above shoulders reflects each movement that a worker makes above the height of her shoulders, as reaching the stripes of the car, gluing blocks in an upper region, (help) fixing the stripes, and taking off of the frames between them before being transported to the pallet or the deposition itself when it is already full. With the reconfiguration, the manual handling actions above shoulders height have been reduced to less than half. These indicators proves that this intervention produced a significant elimination of sources of "Muri".

Summarily, this process constitutes an important ergonomic improvement, reducing the musculoskeletal risk for the shoulders and upper limbs. However, in addition to advantages' assessment, companies must consider the possible limitations and the impact of these interventions on productive processes. The present study demonstrates this and could constitute a guiding example for other companies, since real-industry studies of HRC implementation are scarce [33].
In future work, the materials flow between these workstations (preassembly and final assembly) shall be studied and improved. A longitudinal study based on the work experience with this novel technology is also recommended.

\section{CONCLUSION}

Industry 4.0 demands more flexible industries with improved quality and productivity at the same time workforce must be taken into account by reducing their exposure to risk factors to prevent musculoskeletal disorders. In this sense, collaborative robotics is seen as a new feature of this Industry 4.0 that enables the integration of the accuracy and speed of robots with logical and rational human skills.

In the current study, collaborative robotics integration in the preassembly workstation resulted in a positive impact in terms of ergonomics and production performance. The integration allowed the creation of workstations adapted for workers with physical limitations due to musculoskeletal disorders. Moreover, this implementation had also a positive impact on the downstream manual assembly with improvement in overall performance.

The clear positive contribution of this new configuration in the production process is the reduction of forms of "Muri" and therefore bringing increments in the "respect for people" journey of the company. The other positive aspect is that the labour productivity also increased since some parts of manual tasks are now performed by a robot. Nevertheless, there are also some negative results in terms of the occupied area, an increase of forms of waste ("Muda") such as motion and transport, as well as a higher lead time or throughput time. This negative side is the fact of separating process phases that were performed in the same location (in the initial condition), starting to be performed in three different locations. Since this new condition also created these undesirable effects, as future work, actions must be performed to improve the flow between preassembly and assembly workstations and to decrease the occupied area, as well as other production wastes such as material transportations and material handling.

In future work, the authors intends to conduct a longitudinal study based on the work experience with HRC technology.

\section{ACKNOWLEDGEMENT}

This work has been supported by FCT - Fundação para a Ciência e Tecnologia within the R\&D Units Project Scope: UIDB/00319/2020. This work has also been supported by NORTE-06-3559-FSE-000018, integrated in the invitation NORTE-59-2018-41, aiming the Hiring of Highly Qualified Human Resources, co-financed by the Regional Operational Programme of the North 2020, thematic area of Competitiveness and Employment, through the European Social Fund (ESF).

\section{REFERENCES}

[1] P. Pinheiro, G. D. Putnik, A. Castro, H. Castro, R. D. B. Fontana, and F. Romero, "Industry 4.0 and 
industrial revolutions: An assessment based on complexity," FME Transactions, vol. 47, no. 4, 2019, doi: 10.5937/fmet1904831P.

[2] A. Frank, L. Dalenogare, and N. Ayala, "Industry 4 . 0 technologies : Implementation patterns in manufacturing companies," Intern. Journal of Production Economics, vol. 210, no. January, pp. 15-26, 2019, doi: 10.1016/j.ijpe.2019.01.004.

[3] V. Leso, L. Fontana, and I. Iavicoli, "The occupational health and safety dimension of Industry 4.0," La Medicina del lavoro, vol. 110, no. 5. 2018. doi: 10.23749/mdl.v110i5.7282.

[4] V. Villani, F. Pini, F. Leali, and C. Secchi, "Survey on human-robot collaboration in industrial settings: Safety, intuitive interfaces and applications," Mechatronics, vol. 55, no. February, pp. 248-266, 2018, doi: 10.1016/j.mechatronics.2018.02.009.

[5] J. Huang et al., "A strategy for human-robot collaboration in taking products apart for remanufacture," FME Transactions, vol. 47, no. 4, 2019, doi: 10.5937/fmet1904731H.

[6] D. Antonelli and G. Bruno, "Dynamic distribution of assembly tasks in a collaborative workcell of humans and robots," FME Transactions, vol. 47, no. 4, 2019, doi: 10.5937/fmet1904723A.

[7] A. Cherubini, R. Passama, A. Crosnier, A. Lasnier, and P. Fraisse, "Collaborative manufacturing with physical human-robot interaction," Robotics and Computer-Integrated Manufacturing, vol. 40, 2016, doi: 10.1016/j.rcim.2015.12.007.

[8] P. Maurice, V. Padois, Y. Measson, and P. Bidaud, "Human-oriented design of collaborative robots," International Journal of Industrial Ergonomics, vol. 57, pp. 88-102, 2017, doi: 10.1016 j.ergon.2016.11.011.

[9] A. Colim, C. Faria, N. Sousa, and A. Rocha, "Physical Ergonomic Improvement and Safe Design of an Assembly Workstation through Collaborative Robotics," 2021.

[10] A. Cesta, A. Orlandini, G. Bernardi, and A. Umbrico, "Towards a planning-based framework for symbiotic human-robot collaboration," IEEE International Conference on Emerging Technologies and Factory Automation, ETFA, vol. 2016-Novem, pp. 1-8, 2016, doi: 10.1109/ETFA.2016.7733585.

[11] B. Kadir, O. Broberg, and C. Conceição, "Current research and future perspectives on human factors and ergonomics in Industry 4.0," Computers \& Industrial Engineering, vol. 137, pp. 1-12, Nov. 2019, doi: 10.1016/j.cie.2019.106004.

[12] A. Richert, M. A. Shehadeh, S. L. Muller, S. Schroder, and S. Jeschke, "Socializing with robots: Human-robot interactions within a virtual environment," Proceedings of IEEE Workshop on Advanced Robotics and its Social Impacts, ARSO, vol. 2016-Novem, pp. 49-54, 2016, doi: 10.1109/ARSO.2016.7736255.
[13] H. Stern and T. Becker, "Development of a Model for the Integration of Human Factors in Cyberphysical Production Systems," Procedia Manufacturing, vol. 9, pp. 151-158, 2017, doi: 10.1016/j.promfg.2017.04.030.

[14] S. Fletcher et al., "Adaptive automation assembly: Identifying system requirements for technical efficiency and worker satisfaction," Computers \& Industrial Engineering, p. 105772, Mar. 2019, doi: 10.1016/j.cie.2019.03.036.

[15] D. Romero et al., "Towards a Human-Centred Reference Architecture for Next Generation Balanced Automation Systems : HumanAutomation Symbiosis To cite this version : HAL Id : hal-01431145 Towards a Human-Centred Reference Architecture for Next Generation Balanced Automation," 2017.

[16] V. Lindström and M. Winroth, "Aligning manufacturing strategy and levels of automation: A case study," Journal of Engineering and Technology Management - JET-M, vol. 27, no. 3-4, pp. 148159, 2010, doi: 10.1016/j.jengtecman.2010.06.002.

[17] A. Colim et al., "Towards an ergonomic assessment framework for industrial assembly workstations - A case study," Applied Sciences (Switzerland), vol. 10, no. 9, 2020, doi: 10.3390/app10093048.

[18] A. C. Pereira, J. Dinis-Carvalho, A. C. Alves, and P. Arezes, "How Industry 4.0 can enhance lean practices," FME Transactions, vol. 47, no. 4, pp. 810-822, 2019, doi: 10.5937/fmet1904810P.

[19] J. Womack, D. Jones, and D. Roos, The machine that changed the world. New York: Free Press, 1990.

[20] J. Womack and D. Jones, Lean thinking: Banish Waste and Create Wealth in Your Corporation. New York: Fee Press, 1996.

[21] J. Liker, Toyota Way: 14 Management Principles from the World's Greatest Manufacturer. McGrawHill Education, 2004.

[22] Shingo Institute, "The Shingo Model," 2020. https://shingo.org/shingo-model/ (accessed Jun. 08, 2020).

[23] S. Vicente, A. C. Alves, M. S. Carvalho, and N. Costa, "Business sustainability through employees involvement: A case study," FME Transactions, vol. 43, no. 4, pp. 362-369, 2015, doi: $10.5937 /$ fmet $1504362 \mathrm{~V}$.

[24] Y. Sugimori, K. Kusunoki, F. Cho, and S. Uchikawa, "Toyota production system and Kanban system Materialization of just-in-time and respectfor-human system," International Journal of Production Research, vol. 15, no. 6, pp. 553-564, 1977, doi: 10.1080/00207547708943149.

[25] Toyota_Europe, "The Toyota Way: our values and way of working," 2019.

[26] Hiroyuki. Hirano, JIT implementation manual : the complete guide to just-in-time manufacturing. CRC Press, 2010. 
[27] M. F. Suárez-Barraza, S. M. Dahlgaard-Park, F. G. Rodríguez-González, and C. Durán-Arechiga, "In search of 'Muda' through the TKJ diagram," International Journal of Quality and Service Sciences, vol. 8, no. 3, 2016, doi: 10.1108/IJQSS04-2016-0028.

[28] C. H. Neumann, W.P., Winkelhaus, S., Grosse, E.H., Glock, "Industry 4.0 and the human factor A systems framework and analysis methodology for successful development," International Journal of Production Economics, vol. 20, pp. 30341-8, 2020, doi: https://doi.org/10.1016/j.ijpe.2020.107992.

[29] A. Colim, N. Sousa, P. Carneiro, N. Costa, P. Arezes, and A. Cardoso, "Ergonomic intervention on a packing workstation with robotic aid-case study at a furniture manufacturing industry," Work, vol. 66, no. 1, pp. 229-237, 2020, doi: 10.3233/WOR-203144.

[30] L. B. M. de Guimarães, M. J. Anzanello, J. L. D. Ribeiro, and T. A. Saurin, "Participatory ergonomics intervention for improving human and production outcomes of a Brazilian furniture company," International Journal of Industrial Ergonomics, vol. 49, pp. 97-107, 2015, doi:10.1016 /j.ergon.2015.02.002.

[31] L. McAtamney and N. Corlett, "RULA: A survey method for the investigation of work-related upper limb disorders," Applied Ergonomics, vol. 24, no. 2, pp. 91-99, 1993.

[32] D. Roman-Liu, "Comparison of concepts in easyto-use methods for MSD risk assessment," Applied Ergonomics, vol. 45, no. 3, pp. 420-427, 2014, doi: 10.1016/j.apergo.2013.05.010.
[33] L. Gualtieri, E. Rauch, and R. Vidoni, "Emerging research fields in safety and ergonomics in industrial collaborative robotics: A systematic literature review," Robotics and ComputerIntegrated Manufacturing, vol. 67, no. April 2020, p. 101998, 2021, doi: 10.1016/j.rcim.2020.101998.

\section{ЕМПИРИЈСКА СТУДИЈА УСЛОВА РАДА И ПЕРФОРМАНСИ ПРОДУКТИВНОСТИ ПОСЛЕ ИМПЛЕМЕНТАЦИЈЕ КОЛАБОРАТИВНЕ РОБОТИКЕ У ПРОЦЕСУ ПРОИЗВОДНЕ МОНТАЖЕ}

\author{
А. Колим, Р. Моргадо, Ж. Диниш Карваљо, \\ Н. Соуза
}

Индустрија 4.0 довела је до широко распрострањене и са великим утицајем еволуције технологије која трансформише индустрију и организације уопште. Колаборативна роботика сматра се једном од нових карактеристика овог покрета која омогућава људима и роботима да заједно раде у савршеној сарадњи. Овај рад представља имплементацију једног колаборативног робота у процесу монтаже и анализира његов утицај на перформансе и ергономске услове рада. У погледу ергономских услова, процењен је мускуларно-скелетарни ризик, упоређујући оба процеса (без и са роботском подршком). Резултати су показали да је колаборативна роботика решење које омогућава побољшање ергономских услова рада током целог процеса монтаже. 